\title{
Sistem Informasi Pencatatan Transaksi Berbasis Web Di Badan Usaha Milik Desa(BUMDES) Prasaja Desa Batursari, Kecamatan Batangan Kabupaten Pati
}

\author{
Evanita $^{1}$, Dwyan Akbar Putra ${ }^{2}$, Muhamad Bakhar ${ }^{3}$ \\ e-mail: evanita@umk.ac.id ${ }^{1}, 201751104 @$ std.umk.ac.id ${ }^{2}$, muhammadbakhar@gmail.com ${ }^{3}$ \\ ${ }^{12}$ Prodi Teknik Informatika Fakultas Teknik Universitas Muria Kudus \\ ${ }^{3}$ Prodi Teknik Komputer Politeknik Harapan Bersama Tegal
}

\begin{abstract}
Abstrak
Salah satu tugas Badan Usaha Milik Desa (BUMDES) Prasaja Desa Batursari, Kecamatan Batangan, Kabu-paten Pati adalah pengelolaan dana. Proses perdagangan dan pendataan transaksi pada Bumdes masih menggunakan buku dan belum menggunakan database sehingga rentan terjadinya selisih dan human error. Terjadinya kesalahan yang menyebabkan ketidak efisienan dan memakan waktu cukup lama saat proses perhitungan transaksi, sedangkan data harus segera di olah untuk mengetahui hasil transaksi setiap bulan. Untuk itu dirasa perlu adanya pengembangan perangkat lunak Sistem Informasi Pencatatan Transaksi Ber-basis Web. Perangkat lunak tersebut merupakan sebuah system informasi yang dibutuhkan pihak BUMDES untuk mengetahui hasil transaksi usaha dan data yang diperlukan sewaktu-waktu. Sistem ini menggunakan metode waterfall. Software yang digunakan untuk membangun sistem ini yaitu Visual Studio Code dengan Bahasa pemrograman PHP. Dan menggunakan MySql sebagai penyimpanan Database. Hasil akhir dari system ini diharapkan mempermudah mengelola data pencatatan transaksi pada BUMDES.
\end{abstract}

Kata kunci : Bumdes, Pencatat transaksi.

\section{Pendahuluan}

Pengembangan BUMDES di pedesaan dimak-sudkan untuk memfasilitasi desa menjadi desa otonom dan mandiri. Pembentukan BUMDES akan menjadi instrumen pembentukan dan peningkatan Pendapatan Asli Desa (PADesa). Pembentukan dan peningkatan PADesa akan menjadi modal pemben-tukan kegiatankegatan pembangunan melalui prakarsa lokal (desa), sehingga secara bertahap akan mengurangi ketergantungan terhadap pemerintah, pemerintah provinsi, dan pemerintah daerah. dengan tersedianya dana pengelolaan dan pembiayaan pembangunan untuk desa tersebut. Apabila pembangunan pedesaan dapat berjalan dengan baik, maka diharapkan berdampak pada peningkatan kualitas hidup masyarakat pedesaan. Tersedianya PADesa pemerintah desa akan mem-iliki kemampuan untuk merencanakan dan melaksanakan pembangunan pedesaan untuk keluar dari kemiskinan karena telah memiliki ke-mampuan untuk penyediaan infrastruktur dan fasil-itas-fasilitas penting lainnya[1].

Penemuan teknologi komputer dan informatika sejak awal dimaksudkan untuk membantu menrin-gankan pekerjaan manusia agar lebih efektif dan efisien. Pengolahan data yang sebelumnya dil-akukan secara manual, tidak perlu dilakukan kem-bali karena akan memakan waktu lama serta mem-butuhkan ketelitian yang cukup tinggi. Untuk melakukan hal tersebut, dilakukan perubahan secara keseluruhan terhadap sistem kerja yang awalnya manual menjadi terkomputerisasi.

Proses perdagangan dan pendataan transaksi pada Bumdes masih menggunakan buku dan belum menggunakan database sehingga rentan terjadinya selisih dan human error. Terjadinya kesalahan yang menyebabkan ketidak efisienan dan memakan waktu cukup lama saat proses perhitungan transaksi, sedangkan data harus segera di olah untuk mengetahui hasil transaksi setiap bulan[2].

Berdasarkan permasalahan tersebut maka akan dibuatkan Sistem Informasi Pencatatan Transaksi[3] Berbasis Web. Sistem ini dapat merekap data yang diinputkan dari kasir dari hasil penjualan sehari-hari yang kemudian akan disimpan di database agar aman.

\section{Metode Penelitian}

BUMDES Prasaja Desa Batursari, Batangan, Pati. Mendirikan sebuah unit usaha dagang yang menjual berbagai macam produk kebutuhan masyarakat sekitar, dan produk buatan masyarakat desa Batursari maka diperlukan observasi lapangan untuk mengetahui permasalahan. 
Wawancara dengan manager di BUMDES Prasaja untuk mengetahui mekanisme penjualan juga memantau hasil transaksi. Dari hal tersebut maka munculah pemikiran untuk membuat se-buah sistem informasi pencaatat transaksi dimana informasi dapat dengan mudah diakses dan selalu update tiap periode.

Berdasarkan hasil penelitian sebuah sistem in-formasi pencatatan transaksi dibutuhkan untuk mempermudah Pencatatan transaksi dan pembu-atan laporan transaksi secara online.

Pengumpulan data-data atau informasi mengenai data transaksi sangat diperlukan untuk menunjang analisa sistem yang akan dibuat, dengan tujuan sistem yang akan dibangun sesuai dengan kebutuhan.

Pengetahuan dan teori yang digunakan. Dasar teori lain meliputi sistem pengelolaan metode analisis, perancangan sistem, implementasi dan pengujian sistem. sebagai landasan teori pem-buatan aplikasi Sistem Informasi Pencatat Transaksi. Pengetahuan dan teori yang digunakan analisa perancangan sistem, bahasa pemrograman PHP, MySQL

Pengumpulan data-data atau informasi mengenai data transaksi sangat diperlukan untuk menunjang analisa sistem yang akan dibuat, dengan tujuan sistem yang akan dibangun sesuai dengan kebutuhan.

Dalam pembangunan Sistem Informasi Pen-catatan Transaksi Berbasasis Web di Bumdes Prasaja, Batangan, Pati, metodologi pengembangan yang digunakan adalah pemodelan yang bersifat terstruktur (Structured programming Language), yaitu menggunakan FlowChart, ERD (Entity Relationship Diagram), Schema Jaringan dan DFD (Data Flow Diagram). Oleh sebab itu pengetahuan mendalam tentang perancangan terstruktur sangat dibutuhkan[4].

Proses pengujian sistem dilakukan oleh pengguna, dengan tujuan untuk mengetahui hasil sistem yang telah dibuat. Pengujian dilakukan apabila terjadi kekurangan pada sistem tersebut yang memerlukan perbaikan. Proses pengujian Blackbox melakukan pengujian berdasarkan apa yang dilihat, hanya fokus terhadap fungsionalitas dan output. Pengujian lebih ditujukan pada desain software sesuai standar dan reaksi apabila terdapat bug/vulnerabilitas pada program aplikasi tersebut[5].

\section{Hasil dan Pembahasan}

Data yang dibutuhkan dari Sistem Informasi Pencatatan Transaksi berbasis web di Desa Ba-tursari, Batangan, Pati adalah:

1. Data Barang

2. Data Kategori barang

3. Data Toko

4. Data Pemasukan Uang

5. Data Laba Modal

6. Data Laporan Penjualan

7. Data Laporan Pembelian Beli /stok

8. Data Laporan Pembelian Beli /stok

9. Data penjualan

10.Data pembelian

Pada halaman menu utama admin, admin dapat melihat barang, melihat kategori, melihat pemasukan,melihat laporan, melihat pengeluaran uang modal,melihat laba modal, logout admin.

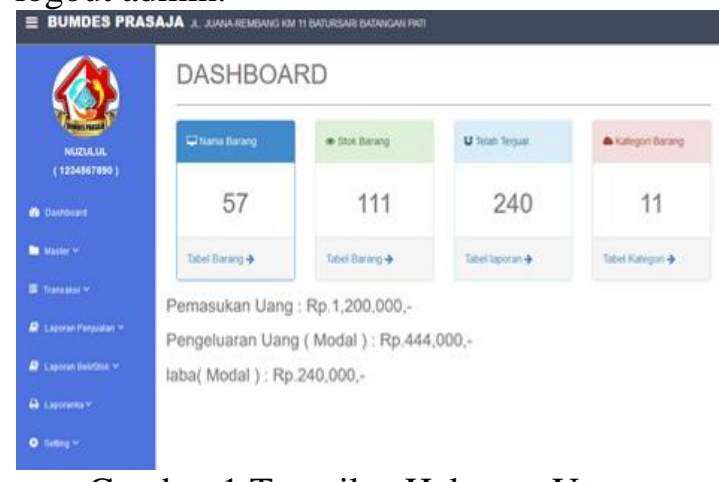

Gambar 1 Tampilan Halaman Utama

Pada halaman laporan, manager dan admin dapat melihat laporan, mencari transaksi berdasarkan kriteria ID barang, Nama barang, periode bulan, tahun, dan mencetak laporan logout admin.

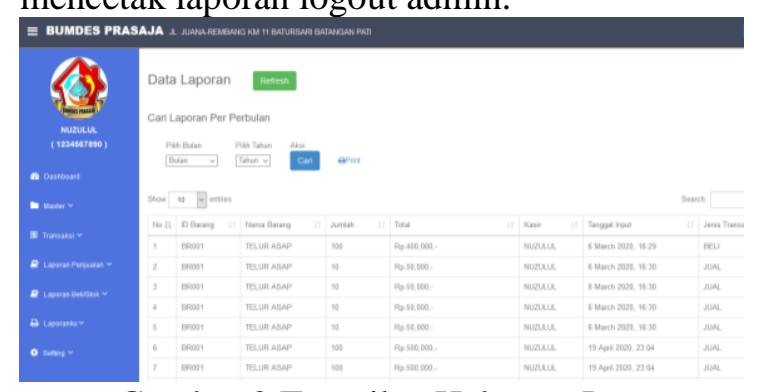

Gambar 2 Tampilan Halaman Laporan

Ketika admin menekan menu Transaksi maka akan menampilkan tampilan pembelian/ stok dan pnjualan seperti gambar di bawah. Pada halaman transaksi-pembelian dan penjualan admin dapat melakukan transaksi barang dengan cara mencari nama barang, 
memillih barang yang di dibeli dan jual, dan jumlah barang, kemudian menyimpan nya. dan tombol logout admin.

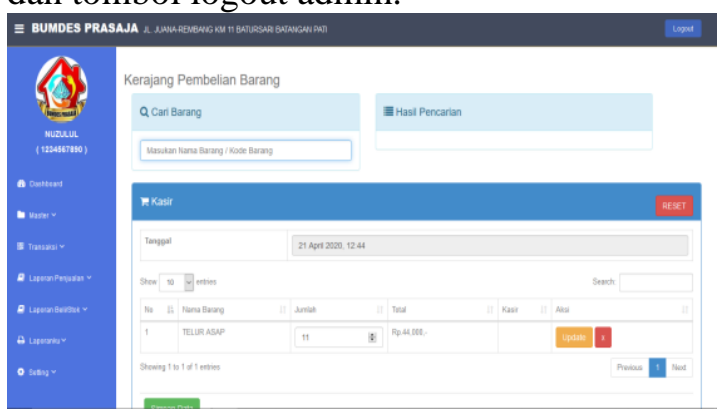

Gambar 3 Tampilan Halaman Transaksi

Ketika admin menekan menu Laporan Penjulana maka akan menampilkan tampilan riwayat penjualan seperti gambar di bawah. Pada halaman laporan, admin dapat melihat laporan, mencari transaksi penjualan berdasarkan kriteria ID barang, Nama barang, periode bulan, tahun, dan tombol logout admin.

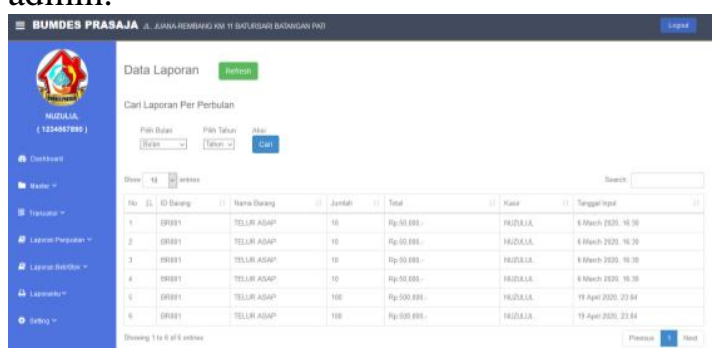

Gambar 4 Tampilan Halaman Laporan Penjualan

Ketika admin menekan menu Laporan Beli/stok maka akan menampilkan tampilan riwayat pembelian/stok seperti gambar di bawah.Pada halaman laporan, admin dapat melihat laporan, mencari transaksi beli/stok berdasarkan kriteria ID barang, Nama barang,periode bulan, tahun, dan tombol logout admin.

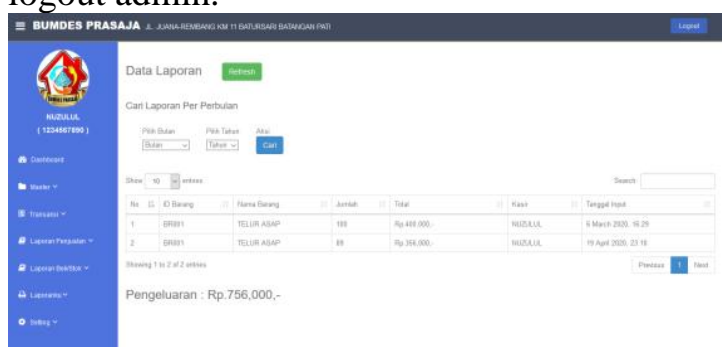

Gambar 3. 5 Tampilan Halaman Laporan Beli/Stok

Pada halaman laporan, manager dan admin dapat, dan mencetak laporan.

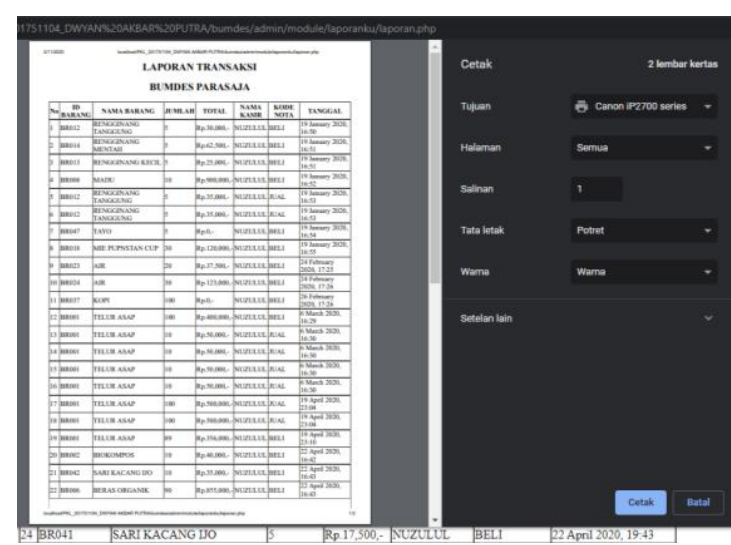

Gambar 3. 6 Tampilan Hasil Cetak Laporan

\section{Kesimpulan}

Hasil yang dicapai dari Praktik Kerja Lapangan di BUMDES Prasaja Desa Batursari, Batangan Pati berupa Sistem Informasi Pencatatan Transaksi Berbasis Web Dalam Sistem tersebut terdapat beberapa layanan, yaitu:

a. Halaman utama admin, berisi dapat melihat barang, melihat kategori, melihat pemasukan,melihat laporan, melihat pengeluaran uang modal,melihat laba modal. ,tombol logout admin.

b. Halaman Laporan, berisi melihat laporan, dan mencetak laporan logout admin.

c. Halaman Transaksi pembelian/stok dan penjualan logout admin.

d. Halaman Laporan Penjualan, berisi, tampilan riwayat penjualan ,logout admin.

e. Halaman Laporan Beli/Stok, berisi tampilan riwayat beli/stok, logout admin.

f. Hasil Cetak Laporan berupa file cetak dari hasil tampilan riwayat penjualan, pembelian/stok .

\section{Daftar Pustaka}

[1] T. T. Loveri, "SISTEM INFORMASI APLIKASI PENGELOLAAN TRANSAKSI KEUANGAN DAN PENDATAAN KONSUMEN PADA CV. PUPLAS," J. Sains dan Inform., 2018, doi: 10.22216/jsi.v4i2.3584.

[2] A. Abdurrahman and S. Masripah, "Metode Waterfall Untuk Sistem Informasi Penjualan," Inf. Syst. Educ. Prof., 2017.

[3] A. Mubarok and S. Hadianti, "Perancangan Program Transaksi Penerimaan Dan Pengeluaran Kas Berbasis Web," J. Inform., 2016.

[4] P. D. Roger S. Pressman, "Rekayasa Perangkat Lunak - Buku Satu, 
Pendekatan Praktisi," in Software Engineering: A Practitioner's Approach, Seventh Edition, 2012.

[5] F. C. Ningrum, D. Suherman, S. Aryanti, H. A. Prasetya, and A. Saifudin, "Pengujian Black Box pada Aplikasi Sistem Seleksi Sales Terbaik Menggunakan Teknik Equivalence Partitions," J. Inform. Univ. Pamulang, vol. 4, no. 4, p. 125, 2019, doi: 10.32493/informatika.v4i4.3782. 